\title{
Impact of Capital Market Development on Economic Growth in Nigeria
}

\author{
Samuel Obafemi Dada \\ Department of Finance, Faculty of Management Sciences, Ekiti State University, Ado-Ekiti, Ekiti State, Nigeria
}

\begin{abstract}
This study appraised the impact of capital market development on economic growth in Nigeria between 1990 and 2015. The study used Gross Domestic Product as the dependent variable and also used foreign direct investment, government expenditure, market capitalization, all share index, number of transactions, credit to private sector and stock turnover ratio as independent variables coupled with the use of the Auto Regressive Distributed Lag (ARDL) model and Granger Causality technique revealing that capital market development has positive effect on economic growth. Hence, it is recommended that participation within the market should be encouraged as various entities within the economy should be encouraged to invest in the capital market through various incentives in a bid to spur economic growth
\end{abstract}

Keywords: Capital Market, All Share Index, Market Capitalization,

\section{INTRODUCTION}

$\mathrm{T}$ The role of the financial system in propelling economic growth cannot be over stressed in literature (Abu, 2009). The financial system embraces the financial institutions such as the central bank, discount houses, deposit money banks, money market, capital market and the interplay of their activities. In the process of intermediation, credit is made available for various purposes within the system in a bid to foster economic growth and development. Correspondingly, Schumpeter (1911) opined that a proper financial system can significantly contribute to economic growth.

However, the need for the interplay within the financial market vis-à-vis economic growth has been hotly contested in literature as various schools of thought have evolved over time to debate over the benefit of the financial market in the economic environment. Schumpeter (1911), Bagehort (1873) and Hicks (1969) averred that the financial market contributes to economic growth significantly as evidenced by the industrial revolution in England as a result of the wellfunctioning banking system. Conversely, Robinson (1952) and Lucas (1988) argued that the financial market does not necessarily bring about economic growth. Nevertheless, the role of the financial market which includes channelization, mobilization and allocation of resources within the economic milieu is still in force (Alile, 1984). Furthermore, focusing on the financial markets and their roles, the money and capital markets seem to come to the fore. However, the capital market has evolved over time to be more renowned and pronounced as it provides the platform for capital trading.
The capital market has been viewed as the institution that improves economic growth and development of developing countries like Nigeria (Osaze, 2000). The capital market embraces all the financial institutions which deal in long term investments. This market can be further segmented into the primary and secondary markets involving the trading in new and existing securities respectively. The capital market provides the funds needed for effective investment in the country and also effectively allocate these funds to projects that will yield the best return to investors (Egwu, 2014). Also, they perform functions relating to the liquidity, collection of information about firms, mitigation of risk, mobilization of savings and corporate control (Anyanwu, 1998), therefore by adjusting the quality of these services, the rate of economic development can be altred (Equakun, 2005). Similarly, the capital market provides cheap source of funds to engender economic development of the economy (Geert, 1997).

The contribution of capital market to economic growth has been viewed to have been enormous and the Nigerian economy is not excluded. Nonetheless, there exists a superfluity of contributions in literature vis-à-vis the impact of capital market development on economic growth (Duke \& Nkamare, 2015; Alshammary, 2014; Alghamedi, 2012; Pan \& Mishra, 2016; Obiakor, 2016; Adan, 2014). Hence, this study will further contribute to the existing body of knowledge on this subject matter from the Nigerian context. Also, taking into cognizance the mixture in literature apropos the impact of capital market development on economic development whereby Schumpter (1911), Bagehort (1873) and Hicks (1969) as corroborated by the findings of Obiakor (2016), Nguyen and Pham (2014), and Ake and Jin (2010) posited that the capital market has a positive impact on economic growth while Robinson (1952) and Lucas (1988) as substantiated by the discoveries of Amu, Nwezeaku and Akujobi (2015), Alghamedi (2012) and Owusu (2016) posited that capital market development has no impact on economic development. Hence, against the backdrop of these controversies, it is imperative to conduct a study to determine the real fact. Hence, this study will adopt the use of the Auto Regressive Distributed Lag modeling technique and the Engle Granger Causality test to examine the subject matter.

\section{LITERATURE REVIEW}

\section{Role of the Capital Market in Economic Development}

The capital market is a market where medium- and long-term finance can be raised (Aiguh, 2013). This market is a platform 
that is provided to deal in long term loanable funds. According to Schumpter (1911), financial markets are the oils to the wheels of economic development; hence, their roles should not be belittled. Correspondingly, Mbat (2001) posited that the capital market is a platform through which funds can be channeled to the deficit unit of the economy from the surplus unit. However, the issue of whether the capital market development contributes significantly to economic growth has been hotly contested in literature. Scholars such as Schumpter (1911), Bagehort (1873) and Hicks (1969) who proposed the finance led economic growth hypothesis assumes that the capital market has a lot of role to play in ensuring economic development. Their argument was supported by the existence of the industrial revolution in England due to the advent of an operational banking system. Congruently, Schumpter (1912) supported his claim by positing that proper intermediation services accelerate innovative and productive activities in the real sector. Conversely, Robinson (1952) and Lucas (1988) saw the role of the capital market has been too overstated in that demand-pull ascendancy from the private sector can instigate the financial sector to respond to the financial needs of the private sector creating demand to cater for the needs of the structure. In Nigeria, the capital market plays some roles in ensuring economic development, some of these roles range from financing infrastructural development to assistance to banks during the consolidation era.

\section{Solow-Swan Theory}

The Solow-Swan theory explains economic development as a function of productivity, capital accumulation, population growth and technological progress (Solow \& Swan, 1956). Hence, there is need for the development of the capital market in a bid to attract capital, boost investment and sour productivity for this is necessary to ensure economic development. The theory which is in line with the exogenous growth theory premised on the assumptions of Harrod-Domar model, three factors have been instrumental to the formulation of the model viz; labour, savings and output which is a function of capital and labour. According to Solow (1956), labour and capital are very instrumental to the production of output. Furthermore, the model assumed that although both factors exhibit constant returns to scale, the labour force is expected to grow at a natural rate considering the exogenous population growth provided there is no technological change. Solow (2000) assumed that steady state of growth is achieved in a situation whereby each factor grows at a constant rate over time, this implies that ratio of capital to output is constant which means capital stock growth. However, the model was found to be defective in that it could not explain per capita income dispersion, it could not address the problem of endogenuity and the assumption that growth rate is not affected by changes in level of investment is not pragmatic.

\section{Endogenous Growth Theory}

The theory as advanced by Schumpter (1942), Romer (1986) and Lucas (1988) who suggested that economic growth is propelled by factors within the economy. Also, this growth rate relies more on the rate of the accumulation of capital. The theory assumed that output and productivity do not depend only on exogenous factors but also on endogenous technology. The theory as supported by Arrow (1962) and Rebelo (1991) assumed that the affiliation between investment and technology diffusion portrays the endogenous nature of the growth process. It was believed that technology diffusion and knowledge diffusion within the economy is also a major determinant of economic growth as firms advance based on innovation which is a function of the fusion of knowledge and technology. This model assumes that output prospers on capital, labour and technology with the assumption that these factors can exhibit either increasing or constant returns to scale. Aghion and Howitt (2009) in support of this theory posited that the sustenance of economic growth can be achieved by saving a fraction of Gross Domestic Product as it can be used to finance technological advancement leading to spurred economic growth. Aside from labour, capital and technology, Romer (1986) assumes that another important factor responsible for growth which is endogenous in nature is knowledge, that is, research and development. The accumulation of knowledge without the interruption of government restrictions can be responsible for growth.

\section{McKinnon and Shaw Theory}

This proposition as advanced by McKinnon (1973) and Shaw (1973) assumes that when real interest rates within the market are kept below the market equilibrium, increase in demand for investment can take place. McKinnon (1973) and Shaw (1973) through the complementarity hypothesis and financial deepening hypothesis explicated the need for markets in ensuring economic growth. The proponents of the McKinnon and Shaw theory refuted the arguments of the classical economists by positing that the financial markets should be liberalized and be allowed to perform without strict restrictions. They assumed that restricting interest rate in the market and controlling investment in the market will reduce growth; hence, there is necessity for the intermediaries like the capital market to allow the market function freely and determine the demand and supply within the economy. This is necessitated by competition in the market which raises interest rates leading to a high savings rate. The Bretton Wood twins (IMF and World Bank) in support of the theory assumed that opening of the financial markets will ensure efficacy in allocation of global capital and development of the market (Zagha \& Nankani, 2005).

\section{Empirical Review from Developed Countries}

Mittal (2017) studied the effect of stock market development on economic growth of nine developed countries between 1990 and 2010. The study used Gross Domestic Product as the dependent variable and also used Market Capitalization as the independent variable coupled with the use of regression technique and the Granger Causality technique; it was revealed that stock market development leads to economic 
growth and vice versa. Hence, it was suggested that policies that will stimulate the financial sector should be formulated and implemented.Pan and Mishra (2016) studied the relationship between stock market development and economic growth of China between 1991 and 2015. The study adopted Industrial production as the dependent variable and also used Market Capitalization as the independent variable connected with the use of regression techniques, it was divulged that stock market has a negative relationship with economic growth. The study recommended that the stock market should be focused upon by policy makers.

Dokmen, Aysu and Bayramoglu (2015) studied the relationship between stock market development and economic growth in eight countries (Brazil, Russia, India, China, Mexico, Indonesia, South Korea and Turkey) between 1991 and 2012. The study adopted Gross Domestic Product as the dependent variable and also used household expenditure, capital formation, government expenditure, trade openness and stock market development as independent variables coupled with the use of the Vector Auto Regressive Model, it was revealed that stock market development has a positive impact on economic growth. Hence, it was suggested that policy makers should reduce the barriers to liquidity in the market.

Nguyen and Pham (2014) studied the relationship between stock market development and economic growth in Canada and Australia between 1981 and 2012. The study adopted Gross Domestic Product as the dependent variable and also used foreign direct investment and market capitalization as independent variables coupled with the use of descriptive statistics and regression techniques; it was revealed that capital market development has a positive impact on economic growth. Hence, it was suggested that the capital market should be promoted to ensure development of the economy.

\section{Empirical Review from Developing Countries}

Coskun, Seven, Ertugrul and Ulussever (2017) studied the nexus between capital market and economic growth in Turkey between 2006 and 2016. The study used Gross Domestic Product as the dependent variable and also used stock market capitalization, stock market traded value, corporate bond market capitalization and total market value of mutual funds and pension funds as independent variables coupled with the use of descriptive statistics and the Auto Regressive Distributed Lag model, it was revealed that capital market development has an uneven effect on economic development. Hence, it was recommended that that an enabling environment should be provided for investment.

Ali and Fei (2016) studied the impact of capital market on the economic growth of Malaysia between 1988 and 2012. The study adopted Gross Domestic Product as the dependent variable and also used market capitalization, foreign direct investment and interest rate as independent variables coupled with the use of regression techniques; it was revealed that capital market development has a positive impact on economic growth. Hence, it was recommended that the government should adopt policies that will foster investment in the economy.

Awan and Iftekhar (2015) studied the influence of stock market development on economic growth in Pakistan between 1988 and 2012. The study used Gross Domestic Product as the controlled variable and also used Stock Market Capitalization, Stock Traded Value and Stock Turnover Ratio as the independent variables coupled with the use of the regression techniques; it was revealed that stock market has a positive affiliation with economic growth. Hence, it was suggested that the capital market should be improved upon by innovation and proper regulation.

Ofori-Abebrese (2015) examined the relationship between stock market development and growth in private investment in Ghana between 1991 and 2011. The study used private investment as the dependent variable and also adopted deposit interest rate, market capitalization, GDP per capita, public investment and inflation rate as independent variables linked with the use of the Auto Regressive Distributive Lag Model (ARDL), it was divulged that there exists a positive and significant relationship between stock market development and economic growth in Ghana. The study further recommended that the investing public should be properly enlightened about the growth spurring effect of the capital market in a bid to embolden economic growth.

\section{Empirical Review from Nigeria}

Azubike (2017) scrutinized the impact of stock exchange on economic growth in Nigeria between 1980 and 2011. The study employed Gross Domestic Product as the explained variable and also used market capitalization, interest rate, total listed securities, total number of issues, number of deals, total number of deals and foreign direct investment as explanatory variables coupled with the use of regression techniques; it was revealed that there exists an inconclusive relationship between the variables. Hence, it was suggested that there is need to stabilize the macroeconomic environment to promote investment in the stock market.

Obiakor (2016) examined the relationship between capital market development and economic growth in Nigeria between 1985 and 2015. The study utilized Gross Domestic Product as the dependent variable and also used market capitalization, value of transactions and all share index as independent variables. The study adopted the classical Ordinary Least Squares regression technique revealing that capital market development has a positive relationship with economic growth. Hence, it was recommended that capitalization of the market should be sustained.

Owusu (2016) studied the relationship between stock market evolution and sustainable economic growth in Nigeria between 1987 and 2014. The study adopted Gross Domestic Product as the predictant and also used foreign domestic 
investment, government expenditure, stock market capitalization, stock value traded, stock market turnover ratio, government expenditure, credit to private sector and the stock market development index as predictors twinned with the use of regression techniques, it was discovered that stock market has no positive effect on economic growth. In the light of this, it was suggested that financial deepening should be improved by removing the obstacles within the financial sectors.

Amu, Nwezeaku and Akujuobi (2015) studied the impact of capital market growth on economic growth in Nigeria between 1981 and 2012. The study adopted Gross Domestic Product as the dependent variable and also used market capitalization and inflation as the independent variables coupled with the use of regression techniques, it was divulged that stock market development does not have significant impact on economic growth. It was therefore recommended that stock market regulatory authorities should adopt policies that enhance the market capitalization to economic growth.

\section{METHODOLOGY}

In conducting this study, secondary data was utilized for the analysis. The data was loglinearized for analysis to avoid spurious results as they were converted to the same base. The study adopted the Auto Regressive Distributed Lag (ARDL) and Engle Granger causality techniques to test for the relationship between capital market development and economic growth. The scope of the study spans from 1990 through 2015. The analysis is conducted utilizing the E-Views 9 statistical package.

\section{Model Specification}

The objective of the study is to empirically appraise the impact of banking sector reforms on economic growth in Nigeria. Hence, the model employed in the study as stated hereunder was adapted from the study of Obiakor (2016).

GDP= $\mathrm{f}$ (FDI, GEXP, MCAPR, ALSI, NUTRAN, CPS, STR, $\mu)$

Where:

$\begin{array}{lll}\text { GDP }= & \text { Gross Domestic Product } \\ \text { FDI }= & \begin{array}{l}\text { Foreign Direct Investmen } \\ \text { GEXP }=\end{array} \\ \text { MCAPR }= & \text { Markernment Expenditure } \\ \text { ALSI }= & \text { All Shapitalization } \\ \text { NUTRAN }= & \text { Number of Transactions } \\ \text { CPS }= & \text { Credit to Private Sector } \\ \text { STR }= & \text { Stock Turnover Ratio } \\ \mu & = & \text { Error term }\end{array}$

Controlled Variable

The study selected Gross Domestic Product as the dependent variable.

\section{Control Variables}

The control variables for the study are foreign direct investment, government expenditure, market capitalization ratio, all share value index, number of transactions, credit to private sector and stock turnover ratio. Data relating to these variables were loglinearized and analysed in a bid to draw proper conclusions and recommendations.

\section{ANALYSIS AND DISCUSSION OF RESULT}

This segment of the study discusses the analysis and result of the study. The regression analysis conducted using E-Views 9. The Auto Regressive Distributed Lag (ARDL) technique is used for analysis. The study used the Schwarz Information Criterion (SIC) for the selection of ARDL (1, 0, 0, 1, 0, 1, 0, $1,1)$

\section{Co-Integration Result}

\begin{tabular}{|c|c|c|}
\hline F-Statistics & Lower Bound (5\%) & Upper Bounnd (5\%) \\
\hline 55.27991 & 2.11 & 3.15 \\
\hline
\end{tabular}

Source: Author's Computation

The F-statistics greater than the upper bound at 5\% significance level shows that there exists a long run relationship among the variables.

Long Run Result

\begin{tabular}{|c|c|c|c|c|}
\hline $\begin{array}{c}\text { Dependent } \\
\text { Variable:- } \\
\text { GDPVariable }\end{array}$ & Co-Efficient & $\begin{array}{c}\text { Std. } \\
\text { Error }\end{array}$ & T-Statistics & Prob. \\
\hline FDI & -0.034129 & 0.064835 & -0.526397 & 0.6101 \\
\hline GEXP & 0.807062 & 0.491199 & 1.643043 & 0.1314 \\
\hline MCAPR & -1.942080 & 0.944492 & -2.056216 & 0.0668 \\
\hline ALSI & 1.050819 & 0.407040 & 2.581610 & 0.0273 \\
\hline NUTRAN & 0.995032 & 0.688803 & 1.444582 & 0.1792 \\
\hline CPS & -0.093364 & 0.478074 & -0.195293 & 0.8491 \\
\hline STR & -1.633851 & 1.026978 & -1.590931 & 0.1427 \\
\hline ECM $(-1)$ & -0.015083 & 0.695725 & -0.021679 & 0.9831 \\
\hline C & -15.06679 & 9.122384 & -1.651629 & 0.1296 \\
\hline
\end{tabular}

Source: Author's Computation using E-Views 9

The long run ARDL result revealed that capital market development has positive effect on economic growth. Also, the result of the normality test, LM Serial Correlation test and the Heteroskedasticity test revealed that there was no problem of abnormal distribution, serial correlation and heteroskedasticity in the model.

Engle Granger Causality Test

\begin{tabular}{|c|c|c|c|}
\hline \multicolumn{4}{|c|}{ Date: $05 / 14 / 21$ Time: 02:13 } \\
\hline \multicolumn{3}{|c|}{ Sample: 19902015} & \\
\hline \multicolumn{2}{|l|}{ Lags: 2} & & \\
\hline Null Hypothesis: & Obs & F-Statistic & Prob. \\
\hline $\begin{array}{l}\text { FDI does not Granger Cause } \\
\text { GDP }\end{array}$ & 24 & 0.57231 & 0.5737 \\
\hline
\end{tabular}




\begin{tabular}{|c|c|c|c|}
\hline \multicolumn{2}{|c|}{ GDP does not Granger Cause FDI } & 2.00397 & 0.1623 \\
\hline $\begin{array}{c}\text { GEXP does not Granger Cause } \\
\text { GDP }\end{array}$ & 24 & 0.42803 & 0.6579 \\
\hline \multicolumn{2}{|c|}{ GDP does not Granger Cause GEXP } & 1.51155 & 0.2459 \\
\hline $\begin{array}{l}\text { MCAPR does not Granger } \\
\text { Cause GDP }\end{array}$ & 24 & 0.16897 & 0.8458 \\
\hline \multicolumn{2}{|c|}{ GDP does not Granger Cause MCAPR } & 7.05772 & 0.0051 \\
\hline $\begin{array}{l}\text { ALSI does not Granger Cause } \\
\text { GDP }\end{array}$ & 24 & 0.40320 & 0.6738 \\
\hline \multicolumn{2}{|c|}{ GDP does not Granger Cause ALSI } & 2.12151 & 0.1474 \\
\hline $\begin{array}{l}\text { NUTRAN does not Granger } \\
\text { Cause GDP }\end{array}$ & 24 & 2.98104 & 0.0748 \\
\hline \multicolumn{2}{|l|}{$\begin{array}{c}\text { GDP does not Granger Cause } \\
\text { NUTRAN }\end{array}$} & 0.40429 & 0.6731 \\
\hline $\begin{array}{l}\text { CPS does not Granger Cause } \\
\text { GDP }\end{array}$ & 24 & 0.76207 & 0.4804 \\
\hline \multicolumn{2}{|c|}{ GDP does not Granger Cause CPS } & 1.70321 & 0.2087 \\
\hline $\begin{array}{l}\text { STR does not Granger Cause } \\
\text { GDP }\end{array}$ & 24 & 3.11308 & 0.0677 \\
\hline \multicolumn{2}{|c|}{ GDP does not Granger Cause STR } & 0.17265 & 0.8427 \\
\hline
\end{tabular}

The Granger causality test revealed that number of transactions and stock turnover ratio causes economic growth while economic growth causes market capitalization.

\section{SUMMARY AND RECOMMENDATION}

This study appraised the impact of capital market development on economic growth in Nigeria between 1990 and 2015. The study used Gross Domestic Product as the dependent variable and also used foreign direct investment, government expenditure, market capitalization, all share index, number of transactions, credit to private sector and stock turnover ratio as independent variables coupled with the use of the Auto Regressive Distributed Lag (ARDL) model and Granger Causality technique revealing that capital market development has positive effect on economic growth. Hence, it is recommended that participation within the market should be encouraged as various entities within the economy should be encouraged to invest in the capital market through various incentives in a bid to spur economic growth.

\section{REFERENCES}

[1] Abu, N. (2009). Does Stock Market Development Raise Economic Growth? Evidence from Nigeria. The Review of Finance and Banking, 1(1), 16-26.

[2] Aghion, P., \& Howitt, P. (2009). The Economics of Growth Cambridge, Massachusetts: The MIT Press.

[3] Aiguh, L. A. (2013). The Impact of Capital Market on the Economic Growth in Nigeria. (B.Sc. Thesis). Caritas University. Nigeria.

[4] Ake, B., \& Jin, D. (2010). The Role of Stock Market Development in Economic Growth: Evidence form Some Euronext Countries. International Journal of Financial Research, 1(1), 14-20.

[5] Alghamedi, A. M. (2012). Assessing the Impact of Stock Market Development on Economic Growth in Saudi Arabia: An Empirical Analysis. (Ph.D. Thesis). Durham University.

[6] Ali, M. A., \& Fei, Y. S. (2016). Impact of Malaysia's Capital Market and Determinants on Economic Growth. Journal of Asian Finance, 3(2), 5-11.
[7] Alile, H. I. (1984). The Nigerian Stock Exchange: Historical Perspectives, Operations and Contributions to Economic Development. Central Bank of Nigeria Bullion, 2(1), 165-169.

[8] Alile, H. I. (1984). The Nigerian Stock Exchange: Historical Perspective, Operations and Contributions to Economic Development. Central Bank of Nigeria Bullion, 2(1), 65-69.

[9] Alshammary, M. J. (2014). An Investigation of the Relationship between Capital Market Development and Economic Growth: The Case of Saudi Arabia. (M.ba. Thesis). Victoria University. Australia.

[10] Amu, C. U., Nwezeaku, N. C., \& Akujobi, A. B. C. (2015). Impact of Capital Market Growth on Economic Growth and Development in Nigeria. American Journal of Marketing Research, 1(3), 93-98.

[11] Anyanwu, J. C. (1998). Stock Market Development and Nigerian Economic Growth. Nigerian Financial Review, 7(2), 6-13.

[12] Arrow, K. J. (1962). The Economic Implication of Learning by Doing. Review of Economic Studies, 29(1), 155-173.

[13] Awan, A. G., \& Iftekhar, U. (2015). How Does Stock Market Development Influence the Economic Growth? International Journal of Economics, Commerce and Management, 3(1), 1-19.

[14] Bagehort, M. (1873). A Description of Money Market with Currency Monopoly. Homewood: ILRichard.

[15] Coskun, Y., Seven, U., Ertugrul, H. M., \& Ulussever, T. (2017). Capital Market and Economic Growth Nexus: Evidence from Turkey. Central Bank Review, 17(1), 19-29.

[16] Dokmen, G., Aysu, A., \& Bayramoglu, M. F. (2015). Linkages between Market Capitalization and Economic Growth: The Case of Emerging Markets. Uluslararasi Ekonomik Arastirmalar Dergisi, 1(1), 39-48.

[17] Duke, S. B., \& Nkamare, S. E. (2015). Impact of Capital Market on the Development of the Nigerian Economy. Archives of Business Research, 3(4), 124-151.

[18] Egwu, M. I. (2014). Impact of Capital Market on Economic Growth in Nigeria (1990-2012). (M.Sc. Thesis). University of Nigeria. Enugu.

[19] Equakun, C. O. (2005). The Nigerian Capital Market: Impact on Economic Growth. (Unpublished M.Sc. Thesis). University of Benin.

[20] Equakun, C. O. (2005). The Nigerian Capital Market: Impact on Economic Growth. (Unpublished M.Sc. Thesis).

[21] Geert, B. (1997). Capital Market: An Engine for Economic Growth. Stanford University.

[22] Hicks, J. (1969). A Theory of Economic History. Oxford: Clarendon Press.

[23] Lucas, E. (1988). On the Mechanics of Economic Development. Journal of Monetary Economics, 22(1), 3-42.

[24] Mbat, D. O. (2001). Financial Management. Uyo: Domes Associates Publishers.

[25] McKinnon, R. (1973). Money and Capital in Economic Development. Brookings Institutions: Washington DC.

[26] Mittal, R. (2017). Effects of Market Capitalization Ratio on GDP Growth and Capital Market Robustness in Newly Industrialized Counties, Chicago Undergraduate Business Journal.

[27] Nguyen, H. T., \& Pham, H. V. D. (2014). Relationship between Stock Market Development and Economic Growth: Evidences from Canada and Australia. International Journal of Economics and Finance, 6(7), 1-10.

[28] Obiakor, R. T. (2016). Does Capital Market Development Spur Economic Growth? A Look at Africa's Largest Economy. The International Journal of Social Sciences and humanities Invention, $3(7), 2397-2406$.

[29] Ofori-Abebrese, G. (2015). Three Essays on Stock Exchange Market Development in Ghana. (Ph.D. Thesis). Kwame Nkrumah University of Science and Technology. Ghana.

[30] Osaze, B. E. (2000). The Nigeria Capital Market in the African and Global Financial System. Bofic Consults Group Limited.

[31] Owusu, E. I. (2016). Stock Market and Sustainable Economic Growth in Nigeria. Economies, 4(25), 1-13.

[32] Pan, L., \& Mishra, V. (2016). Stock Market Development and Economic Growth: Empirical Evidence from China. Monash Business School Discussion Paper Series 16. 
[33] Rebelo, S. (1991). Long Run Policy Analysis and Long Run Growth. Journal of Political Economy, 99(1), 500-521.

[34] Robinson, J. (1952). The Generalization of the General Theory in the Rate of Interest and Other Essays. London: Macmillan.

[35] Romer, P. (1986). Increasing Returns and Long Run Growth. Journal of Political Economy, 94(1), 1002-1037.

[36] Schumpter, J. (1911). The Theory of Economic Development. Cambridge: Harvard University Press.

[37] Schumpter, J. (1912). Capitalism, Socialism and Democracy. Harper, New York.

[38] Shaw, E. S. (1973). Financial Deepening in Economic Development. Oxford University Press. New York.

[39] Solow, R. M. (2000). Growth Theory: An Exposition (2 ${ }^{\text {nd }}$ Ed,): Oxford University Press.

[40] Solow, R. M., \& Swan, T. W. (1956). A Contribution to the Theory of Economics and Capital Accumulation. Quarterly Journal of Economics, 70(1), 65-94.

[41] Zagha, R., \& Nankani, G. T. (2005). Financial Liberalization: What Went Right, What Went Wrong in Economic Growth in the 1990s: Learning from a Decade of Reform. IMF Papers. 